\title{
Post-neoliberalism in Latin America: Rebuilding and Reclaiming the State after Crisis
}

\section{Jean Grugel and Pía Riggirozzi}

\begin{abstract}
The idea that states should take on an enhanced role in the pursuit of development is once again becoming increasingly pronounced in the global South. In Latin America, the 'return of the state' is associated with neostructuralism or post-neoliberalism and the rise of the New Left. Post-neoliberal projects of governance seek to retain elements of the previous export-led growth model whilst introducing new mechanisms for social inclusion and welfare. In addition to being a project of growth based on exports and expanded social spending, post-neoliberalism has a distinctive political character. This article explores the pillars of the new governance project, emphasizing the citizenship claims associated with it, along with some of the tensions that arise from export-dependent growth, budget limitations, a weak tax base and the difficulties of managing enhanced social expectations. In making their argument, the authors draw on the examples of Bolivia, Ecuador and Argentina.
\end{abstract}

\section{INTRODUCTION}

'This is a paradigm shift with society'.

Cristina Fernandez de Kirchner, Página 12, 10 June 2011

Twenty years ago, debates in the political economy of development were dominated by indebtedness, the challenges of growth and welfare in times of austerity and the absence of any apparent margin for policy choice (Haggard and Kaufman, 1992; Nelson, 1989; Stallings, 1992). To an extent, similar dilemmas face global policy makers today in the wake of the 2007/2008 financial crisis. But the context is different. The old hierarchies that shaped the global political economy in the 1990s are in a process of mutation as a result of Chinese economic growth; the difficulties facing Anglo-American and European capitalism; rising global demand for primary commodities which has transformed international trade and enhanced policy space for 'rising

The authors would like to thank Paul Mosley and Jojo Nem Singh as well the referees for comments on an earlier version of this paper.

Development and Change 43(1): 1-21. DOI: 10.1111/j.1467-7660.2011.01746.x

(C) 2012 International Institute of Social Studies.

Published by Blackwell Publishing, 9600 Garsington Road, Oxford OX4 2DQ, UK and 350 Main St., Malden, MA 02148, USA 
powers' and resource-rich 'emerging' countries; and the undermining of the old certainties about orthodox economic policy because of the sometimes over-zealous embrace of the market in the 1990s (Peck et al., 2010). One response to the contemporary challenges of growth in the global South is to try not more of the same but to emphasize instead the role of domestic markets and consumption for growth and the introduction of policies that address the poverty legacy (te Velde, 2008). This is no simple return to the economics of the past, however, for the new policies are being put in place alongside the retention of key elements of economic management from the neoliberal era that are deemed essential for economic stability. This is the approach that is emerging in parts of Latin America where it is also accompanied by increased demand for citizenship from below. Given the weight of neoliberalism in development in recent decades, the emergence of more heterodox political economy(ies) in the global South is important in its own right, but these experiments also offer an intriguing entry point into contemporary debates about financial crisis and the global political economy (Hay, 2010).

In Latin America, attempts to articulate a new political economy of development began gradually around the turn of the millennium as a series of left, or left of centre, governments took office, promising an end to the cautious pro-elite era of democratization and a more expansive approach to welfare spending (Panizza, 2005, 2009; Przeworski, 2011). Alejandro Foxley (2010) has described new left governance economically as a demand for more 'state' and less 'market', whilst the quote above shows that for Cristina Fernandez de Kirchner, President of Argentina, the changes suggest a genuinely new era and a 'paradigm shift with society'. In fact, the significance of post-neoliberalism is perhaps more subtle than President Fernandez de Kirchner implies and it is certainly a rich source of polemic, academically and politically (see, for example, Castaneda and Morales, 2008; Lievesley and Ludlam, 2009; Peck et al., 2010; Roberts, 2008). We try here to chart a middle way, offering a critical analysis that goes beyond a simple dichotomy of state vs. market or 'good' or 'bad' paradigms for growth. We do not conceive of states and markets as a zero-sum game or suggest that 'more state' necessarily means the elimination of market mechanisms; nor do we assume that 'more state' always leads to better governance. As such, we explore both the strengths and the weaknesses of the ways in which the state-market-society nexus is being re-imagined and recast.

We do so drawing principally on the examples of Bolivia, Ecuador and Argentina, leading examples of the post-neoliberal trend in the region, although we also make some references to the more controversial project in Venezuela under Hugo Chavez. Organizationally, the paper is structured around the distinctive pillars associated with post-neoliberalism, namely the set of political aspirations centred on 'reclaiming' the authority of the state to oversee the construction of a new social consensus and approach to welfare, and the body of economic policies that seeks to enhance or 'rebuild' the capacity of the state to manage the market and the export economy in 
ways that not only ensure growth but are also responsive to social need and citizenship demands. In short, we understand post-neoliberalism to be more than simply the 'return of the state' in terms of the economy (Grugel and Riggirozzi, 2007). It is also a call for a new kind of politics, rooted in and responsive to local traditions and communities, and an attempt to forge a new pact between society and the state. We begin with an exploration of the background to post-neoliberalism in Latin America.

\section{SOMETHING OLD, SOMETHING NEW: THE MEANING AND THE ROOTS OF POST-NEOLIBERALISM}

Deregulation of the economy has been a controversial project since the 1970s when it began to gather momentum. It is not surprising that, even in the core of the global economy, doubts have been expressed as to the wisdom of trusting too much to the market in the wake of the 2007/2008 financial crisis (Gamble, 2010; Sachs, 2010). Interestingly, in Latin America the politics and economics of deregulation were questioned somewhat earlier. Political and economic breakdowns in Argentina after 2001 and Venezuela after 1998, and widespread social protests in Ecuador and Bolivia in the early years of the twentieth century, culminated in the election of governments committed to the introduction of counter-cyclical policies, programmes of national (and sometimes regional) economic investment and the extension of social policy coverage. It would be an over-statement to suggest that these changes, important though they are, represent the beginning of a wholly new paradigm for regional development policy, given the strength of neoliberalism as a 'flexible mutating regime' (Peck et al., 2010: 95). New development paradigms are rare: they 'emerge by default, trial-and-error and compromise, and take years to crystallize; and they are often plagued by internal consistencies' (Haggard, 1990: 23). But there is nonetheless sufficient evidence of changes in the way development is framed for scholars to speak confidently of 'neostructuralism' (ECLAC, 2007) or 'post-neoliberalism' as something sufficiently distinct from the consensus that reigned in the 1990s to merit investigation (Grugel and Riggirozzi, 2007, 2009; Hershberg and Rosen, 2006; Roberts, 2008; Ruckert and MacDonald, 2010).

What, then, does 'post-neoliberalism' mean? Rather than proposing a simple, monochromatic answer along the lines of more or less 'state', we understand it to embody a different conceptualization of the state from that which reigned in the high period of neoliberalism, based on a view that states have a moral responsibility to respect and deliver the inalienable (that is, not market-dependent) rights of their citizens (see Almeida and Johnston, 2006: 7), alongside growth. Politically, post-neoliberalism is a reaction against what came to be seen as excessive marketization at the end of the twentieth century and the elitist and technocratic democracies that accompanied market reforms. The political project associated with 
post-neoliberalism, which has sometimes been mistaken for a simple return to populism (Castaneda, 2006), is best understood as a call for a 'new form of social contract between the state and people' (Wylde, 2011: 436) and the construction of a social consensus that is respectful of the demands of growth and business interests and sensitive to the challenges of poverty and citizenship. It is, as such, part of an unfinished debate over what constitutes the transition to democracy (Peruzzotti, 2006: 209). But changes to the portfolio of state responsibilities and a vision of a more equal distribution of national income sit alongside strong continuities from the recent past, in particular the retention of the export axis and commitment to a degree of fiscal restraint that are seen as essential for economic stability. Postneoliberalism is, then, an evolving attempt to develop political economies that are attuned to the social responsibilities of the state whilst remaining responsive to the demands of 'positioning' national economies in a rapidly changing global political economy. Crucially, in much of Latin America it is emerging in the context of an unprecedented export bonanza that permits the adoption of more expansive public spending than has been the case since the 1980s.

The starting point for understanding post-neoliberalism is the neoliberal revolution itself. To summarize briefly what is now well known, the combined effects of the end of communism, the dramatic economic collapse in the developing world in the wake of the debt crisis of the early 1980s, and the rise of global finance in the 1980s and 1990s contributed to the rise of liberal ideas linking development to freeing markets. The result was a convergence amongst business, international aid agencies, financial institutions and governing elites that development required rolling back the state (Babb, 2009). The template for Latin America's engagement with neoliberalism was the Washington Consensus - the name an indication of how far neoliberalism was leveraged by the US and the international financial institutions. The Washington Consensus set out to transform economic practices across Latin America via a range of policies from the privatization of public assets to cuts in public expenditure, and it played well at a time of conservative and timid democratization when the 'excesses' of the Left were blamed for having provoked the violence that engulfed much of the region in the 1960s and 1970 s.

There is some evidence to suggest that neoliberalism reduced state corruption, controlled inflation, and led to improvements for consumers through cheaper imports, more competitive pricing structures and improved access to new technologies (Gwynne and Kay, 2000). But economic restructuring also increased unemployment to levels that sometimes exceeded those of the so-called 'lost decade' of the 1980s. In Argentina, an extreme case, unemployment rose from 8.8 per cent in 1990 to 19.7 per cent in 2002. Across the region, the number of people living in poverty was higher by the end of the 1990s than in 1980, while the percentage of people in poverty remained startlingly high (see Table 1; also ECLAC, 2010a: 11). 
Table 1. Poverty and Extreme Poverty in Latin America, 1980-1999

\begin{tabular}{cccccc}
\hline & \multicolumn{2}{c}{ Poverty } & & \multicolumn{2}{c}{ Extreme Poverty } \\
\cline { 2 - 3 } \cline { 5 - 6 } & $\begin{array}{c}\text { Millions of } \\
\text { People }\end{array}$ & $\begin{array}{c}\text { Percentage of } \\
\text { Population }\end{array}$ & & $\begin{array}{c}\text { Millions of } \\
\text { People }\end{array}$ & $\begin{array}{c}\text { Percentage of } \\
\text { Population }\end{array}$ \\
\hline 1980 & 135.9 & 40.5 & 62.4 & 18.6 \\
1990 & 200.2 & 48.3 & 93.4 & 22.5 \\
1997 & 203.8 & 45.7 & 88.8 & 19.0 \\
1999 & 211.4 & 43.8 & 89.4 & 18.5 \\
\hline
\end{tabular}

Source: ECLAC (2004: 35).

There were also negative consequences for the region's nascent democracies. 'Third wave' transitions addressed the challenge of building stable democratic institutions at the expense of tackling the social debt and the region's exceptionally high rates of inequality (with the exception of Chile; see Taylor, 1999). Since market opening occurred simultaneously with democratization, the pursuit of economic liberalization shaped the culture and practice of politics, encouraging technocratic decision making and reducing popular access to the state (Silva, 2008). Periodic episodes of resistance to the ways in which government policy undermined community and working class organizations erupted through the 1990s in Venezuela, Bolivia, Ecuador and, eventually, Argentina, in addition to other countries of the region (Eckstein and Wickham-Crowley, 2003). Indeed, in the end, it was the association of neoliberalism with ruling class politics (Harvey, 2005) and the difficulty of reconciling neoliberal policies with popular expectations of a new era of democratic politics rather than simply a failure of its economic rationale that led to its unravelling. Governments committed to change were voted into office from 1998 onwards with promises of greater inclusion and policies to stimulate growth and promote human development. Tockman (2010) captures the mix of ideas that lay behind these new left projects as a combination of Keynesian welfare politics, socialism and social democracy (see also Panizza, 2005, 2009).

In short, post-neoliberalism combines an attempt to refocus the direction and the purpose of the economy through state spending, increased taxation and management of exports (Grugel and Riggirozzi, 2007, 2009) with a project of enhancing citizenship, for example through a new politics of cultural recognition in Bolivia and Ecuador (Albro, 2005) or attempts to recreate the state-sponsored productivist pact between business and labour in Argentina (Etchemendy and Collier, 2007). This has gone hand-in-hand with a refashioning of the institutions of the state, sometimes embodied in new constitutions, and a search for a closer, more direct relationship between the executive and the 'people' which has opened governments up to charges of populism or 'hyper-plebiscitary' presidentialism (Castaneda, 2006; Conaghan, 2008). Yet in practice, post-neoliberal governments have tended to be perhaps surprisingly pragmatic, especially in so far as the 
economy is concerned, where policies work with the grain of a liberalized global economy. The contrast between neoliberalism and post-neoliberal growth strategies, in other words, is there; but it should not be drawn too starkly. In the end, the biggest difference lies in government attitudes to the poor and discourses of citizenship rather than economic management as such. Finally, we should note the crucial fact that post-neoliberal governance has been made possible by the rising demand globally for regional exports, especially natural resources. Between 2000 and 2008 the volume of regional exports rose by a remarkable 42.4 per cent (ECLAC, 2009), allowing states to accumulate sufficient resources for redistribution and the design of new social policies. This is important. It suggests the contingency of the current approach to development and it points to a full acceptance of the global economy on the part of the left - and the political and economic risks associated with a return to commodity dependence.

\section{RECLAIMING THE STATE}

Latin American democratization resulted from the 'establishment of a substantive consensus among elites concerning the rules of the democratic game and the worth of democratic institutions' (Burton et al., 1992: 3). Elite pacts facilitated 'an institutional breakthrough' (O'Donnell and Schmitter, 1986: 37), while careful institutional engineering made them more stable than in the past. But the elite pacts that underpinned the new democracies also cemented in place the privileges of the political class (Hagopian, 1992). In the face of public service retrenchment, meanwhile, governments sought to associate democratic citizenship with choice and consumption rather than agency (Oxhorn, 2009). In short, emerging democracies took shape principally round the challenges of embedding representative institutions, somewhat separated from questions of social welfare.

It is perhaps not surprising, in these circumstances, that democratization coincided with a deterioration in living standards and social provision that affected not just the urban and rural poor but also many of the public sector-dependent middle class, as declining investments in public education and privatization of health insurance and higher education cut away at their established standards of living (Birdsall and Lodono, 1998; Portes and Hoffman, 2003). Many of these groups were not protected by the new generation of targeted social welfare policies (Isuani, 2010). For the urban working class, neoliberal policies adjusted the balance of power between the state and the working class, making it difficult to achieve significant wage increases even in moments of growth (Cook, 1998). But, it is important to note, the return of democracy also meant that the labour movement could not be actively repressed and, as Eckstein (2006) shows, labour organizations were sometimes able to shift the locus of protest from the workplace, where they were often subject to stringent new restrictions, to the neighbourhood, 
as in Bolivia in 2003. Labour unions were also able to use episodes of economic crisis to reassert their authority, for example in Argentina in 2001. For indigenous groups, meanwhile, the encroachment of traditional land, environmental degradation and the loss of livelihoods associated with the intensification of export production resulted in community disruption, pauperization and dissatisfaction with traditional elite-based politics (ECLAC, 2010b). Nevertheless, the new democracies permitted indigenous groups access to the party system for the first time (Van Cott, 2005).

Democratization expanded the scope for citizenship mobilization against the routinized dynamics of exclusionary economic policies in the streets, through neighbourhood organizations and within new political parties. Demands for higher public spending and more inclusive democratic governance erupted steadily from the end of the 1990s. In Bolivia, protest against the privatization of water in 2000 and gas in 2003 led to the dramatic collapse of Gonzalo Sánchez de Lozada's second presidential term in October 2003 and brought Evo Morales, indigenous leader of the union of coca producers and the Movimiento al Socialismo (MAS) to power. In Ecuador, the indigenous movements Movimiento Indio Pachakutik (MIP) and CONAIE demonstrated their power of veto by forcing Abdalá Bucaram and Jamil Mahuad out of office in 1997 and 2001 (Sader, 2008). Rafael Correa was elected with indigenous support in 2006, explicitly promising to bring to an end the country's 'long night' of neoliberal adjustment. In Argentina, complete economic collapse in December 2001 led to astonishingly abrupt pauperization, road blocks, factory take-overs and the rise of cross-class demands for a new strategy for growth, better political leadership and the introduction of more comprehensive anti-poverty policies (Feijoo, 2001; Riggirozzi, 2009).

The result was a widespread rejection of the generation of political leaders who had controlled the transitions to democracy in the 1980s and 1990s. The new left that came to power as a result benefited to some extent from the swing against incumbent governments. But the new governments were also accompanied by popular calls for a different kind of political leadership, demands that ordinary people have more access to the state and better welfare provision and mobilization for policies of cultural recognition and a strengthening of communal and indigenous rights (in Bolivia and Ecuador especially). The new constitutions in Bolivia (2009) and Ecuador (2008) codify multicultural entitlements, introduce new forms of representation and deliberation and identify state responsibilities in health, housing and social provision (Tockman, 2010: 25). Moreover, these reforms are taking place in the context of re-energized local or base level politics. In Bolivia in particular, the neighbourhood has become a vital organizing space, allowing claims to be made against the state and substituting local political identities for national ones (Lazar, 2008). In Argentina, meanwhile, working class politics escaped the control of the Peronist elite during the economic crisis of 2001, leading to the formation of a Movement of the Unemployed (MST), 
factory take-overs and the emergence of a street vendor movement, all rooted in local community and union activism (Dinerstein, 2007). In both Bolivia and Argentina, these local movements draw on deeply rooted traditions of organization based on demands for improved service provision (Goldfrank, 2011; Goldfrank and Shrank, 2009) and, as such, they are unlikely to prove easy for even a strengthened executive to control.

While the potential for protest from below is now relatively contained in Argentina as a result of the state's largely successful management of the labour movement (Wylde, 2011), local demands have the potential to engender conflicts with the government in Bolivia and Ecuador. The governments of Morales and Correa will almost certainly pay a price electorally if they ignore the politics of the streets or do not deliver the social inclusion and welfare that has been promised. Much depends on how well they are able to manage the strategy of linking export taxes to welfare expansion and the management of natural resources; there are intrinsic tensions here that require careful handling. In general, indigenous communities resist further commodification and foreign ownership or exploitation of land they hold sacred. As leader of the anti-neoliberal protests in 2003, Evo Morales, now President of Bolivia, argued that the struggle to 'reclaim our natural resources' was a continuation of the fight against ' 500 years' of indigenous oppression, or the 'culture of life represented by the indigenous people' against the 'culture of death represented by the West' (Morales, 2005). Yet governments in both countries are committed to maximizing revenue from the rising global demand for energy as a way of subsidizing welfare (Gudynas, 2010; Stokes, 2009). Doing so without provoking open resistance requires constant, delicate negotiation and there is no guarantee of success, as the wave of indigenous protests against development in the Bolivian Amazon in August and September 2011 demonstrates.

Given the generally low base of social spending which pertains across the region (with the exception of Chile), post-neoliberal governments have been able to score quick wins with regard to welfare thus far. In Venezuela, where high value resources are of course most abundant, an impressive series of poverty alleviation programmes, especially in urban areas, has been underway since the 1990s. These include the introduction of universal education and health care through what are termed de-centralized 'missions' (Misiones) that replace state-led programmes. Programmes range from Misión Ribas (adult education) and Misión Sucre (university scholarships) to Misión Vuelvan Caras (economic cooperatives), Misión Guaicaipuro (indigenous land titling), Misión Barrio Adentro (community health), Misión Mercal (subsidized food markets) and Misión Milagro (eye operations, which provides free surgery in Cuba to Venezuelan and other Latin American citizens) (see Kozloff, 2008). In Bolivia and Ecuador the inflow of resources from export taxes has also permitted a substantial increase in welfare spending, though not at levels comparable to those of Venezuela. In Bolivia, the forced renegotiation of contracts within the energy sector in 2005 was followed by 
a Hydrocarbons Law in 2008 that introduced an 18 per cent royalty tax and a 32 per cent direct tax (Benton, 2008). At the same time, the state increased its own stake in the energy sector and profits from energy exports fund the new social programmes (Kaup, 2010). Likewise, in Ecuador the Correa government increased export taxes and renegotiated contracts with the oil companies in order to generate a surplus for welfare spending. ${ }^{1}$ In both countries, the welfare programmes build largely on already existing targeted cash-transfer programmes. In Bolivia, the new programmes include a cash transfer scheme for school age children linked to school attendance (the Juan Pinto programme), introduced in 2006, that reaches over a million children. There is also a programme for the elderly that provides some coverage for those without, or with only a very low, pension (Gray Molina, 2008). Bolivia has also benefited from a kind of 'trans-nationalized welfarism', or social policy subsidies from Venezuela (Murh, 2010).

Argentina, meanwhile, also introduced a 20 per cent tax on export earnings from agricultural commodities and hydrocarbons, as well as new taxes on mining exports, which became the source of funding for the emergency programmes introduced after 2002 - though not without vocal opposition from export elites. Tax on sales and export revenues have allowed the Kirchner governments to introduce or extend targeted cash transfer programmes, including the Unemployed Men and Women Heads of Households Programme (Programa Jefas y Jefes de Hogares Desempleados), which was instrumental in dealing with the abrupt rise in poverty after the financial collapse of 2001, from 28 per cent in May 1998 to 38 per cent by October 2001 and 57.5 in early 2002 (World Bank, 2003: 5). Jefas y Jefes was initially viewed as a time-limited solution but it was extended after it became apparent, the return to economic growth after 2003 notwithstanding, that the poverty legacy of the 1990s and the rapid pauperization after the crash demanded sustained action. The government of Cristina Fernandez de Kirchner also introduced a targeted programme for children, the Universal Child Benefit (Asignación Universal por Hijo or AUH) in 2010. This provides around 200 Argentine pesos (US\$ 50) a month for nearly 4 million children and families (Cogliandro, 2010). The programme is significant in that, really for the first time, the government is extending welfare programmes directly to children and to workers who are not unionized. Numerically, most beneficiaries will be from within the informal or self-employed sectors (Página 12, 2 December 2010), groups that were particularly active in the protests of 2001. Further evidence of state mediation in welfare in Argentina includes the creation of a 'reasonable' minimum wage for non-unionized workers (including domestic servants) in 2008 and pressure on the private health companies to extend their coverage and reduce their charges (La Nación, 18 December 2008).

In all three countries, social spending on this scale is both a signal of government commitment to welfare and a sign, more broadly, that the state

1. For further details, see Clements et al. (2007). 
Table 2. Poverty and Extreme Poverty in Latin America, 2002-2010

\begin{tabular}{cccccc}
\hline & \multicolumn{2}{c}{ Poverty } & & \multicolumn{2}{c}{ Extreme Poverty } \\
\cline { 2 - 3 } & Millions of People & Percentage & & Millions of People & Percentage \\
\hline 2002 & 221.4 & 44.0 & & 97.4 & 19.4 \\
2007 & 184.4 & 34.1 & & 68.4 & 12.6 \\
2008 & 180 & 33.0 & & 71 & 12.9 \\
2009 & 183 & 33.1 & & 74 & 13.3 \\
2010 & 180 & 23.1 & & 72 & 12.9 \\
\hline
\end{tabular}

Source: ECLAC (2010a: 11).

wants to be seen as being on the side of the working class, the lower middle class and the poor, rather than captured by elite groups (Mosley et al., forthcoming). And undoubtedly, especially in the current context of growth, the reforms are bearing fruit. There has been a steady decline in poverty since the mid-2000s and most especially since 2006 (Lopez-Calva and Lustig, 2010; Lustig and McCloud, 2009). According to ECLAC (2010a: 13) the percentage of people living below the poverty line fell significantly after 2002 (see Table 2). In Argentina, levels of poverty have now retreated to their 'normal' level of around 11 per cent from a peak of over 45 per cent in 2002. In Bolivia, the number of those classified as 'poor' dropped from 62 per cent of the population to 54 between 2008 and 2010. The percentage of Venezuelans living below the poverty line fell from 49.4 per cent in 1999 to 27.6 in 2008; while in Ecuador, the number of people living in poverty has fallen by around 10 per cent in the last seven years. Inequality seems also to be reduced, by as much as 18 per cent in Venezuela and more moderately in Argentina (by 10 per cent) and Bolivia (8 per cent) (ECLAC, 2010b). Furthermore, the new cash transfer programmes, in particular those that release funds for education attendance and health care, are almost certainly reaching groups that did not benefit previously from state programmes (UNDP, 2010).

Extending cash transfers certainly has immediate results but, as Green et al. (2010) suggest, the long-term impact of the programmes is more limited. Regionally, poverty still stands at 33 per cent (ECLAC, 2010b). Governments face difficult decisions about spending since policies based on targeting and incentives reduce the worst manifestations of poverty but tend not to tackle underlying inequality (Cortes, 2009). Doing so demands quite different sorts of interventions. In particular, it requires a comprehensive change to the tax system that shifts the burden from sales and export taxes to direct tax based on income and property (Centeno, 2009; Lo Vuolo et al., 2010), as well as action to address tax evasion, which currently stands at around 50 per cent or more (see Birdsall et al., 2009). Governments in Latin America, on the right and the left, have traditionally shied away from tax reform because of the political costs. Tackling tax evasion and expanding the tax base carry with them the risk of conflict with both domestic tax 
payers and corporate investors (OECD, 2010). For left governments, it has the additional risk of potentially opening up a conflict with the sizeable number of informal earners, who would have to be brought into the formal economy. The scale of the reforms required to seriously address inequality, in short, cannot be underestimated, nor can the political sensitivities that potentially attach to them. As the World Bank (2004) — which has argued for tax reform in Latin America for decades - notes, reform depends on building a pro-reform 'political and social consensus', something that is notoriously difficult to achieve (Lledo et al., 2010), especially in the current, highly politicized climate.

\section{REBUILDING THE STATE}

A sense that the high period of neoliberalism was drawing to a close was evident as early as the end of the 1990s in the World Bank (Chorev and Babb, 2009) as well as the Inter-American Development Bank (IADB) (Birdsall and de la Torre, 2001). The IADB had noted the failure to tackle poverty and social exclusion in the 1990s and codified its own approach to growth based around a more proactive state in The Politics of Policies (IADB, 2006). ECLAC, meanwhile, restated its proposals for growth with equity and called for a new focus on production partnerships between the state and business (see ECLAC, 2007; Leiva, 2008). The point we are making here is that there was a growing consensus, extending beyond the left, about the need for states to actively encourage production, strengthen their regulatory and fiscal capacities and address the social debt. Ruckert and Macdonald (2010) refer to the policies that ultimately emerged as the return of the 'developmentalist state'. But it is also the case that, whilst governments are seeking to enhance their policy autonomy and expand their space for policy innovation, meaning that industrial policy, infrastructural development and higher corporate taxes are now back on the agenda, innovation in these areas sits alongside the retention of neoliberal legacies around 'responsible' fiscal policy and export expansion.

Discussion about the need for a 'more intelligent state' (Kirchner, cited in Vilas, 2006) to harness growth has had an evident impact in those countries where state-centric development or import substituting industrialization had once provided the basis for prosperity, Argentina most notably. ${ }^{2}$ Assessed soberly, growth in the ISI period, though far from spectacular, was in fact considerably more respectable than it was often portrayed in the 1980s and 1990s, especially in comparison with the later period (see Table 3).

2. Although we should note that regional interest in heterodox policy making overall seems to be growing. The UNASUR Summit in Buenos Aires in 2011 concluded by supporting the introduction of joint stimulus policies as a way of protecting the region from fallout from the global crisis (Página 12, 29 July 2011). 
Table 3. Average Per Capita Growth

\begin{tabular}{lccc}
\hline & $\mathbf{1 9 6 0 - 2 0 0 2}$ & $\mathbf{1 9 6 0 - 1 9 8 0}$ & $\mathbf{1 9 8 1 - 2 0 0 2}$ \\
\hline Argentina & 0.9 & 2.6 & -0.6 \\
Bolivia & 1.0 & 2.3 & -0.3 \\
Ecuador & 2.0 & 5.4 & -0.2 \\
Venezuela & 0.1 & 1.6 & -1.3 \\
\hline
\end{tabular}

Source: Solimano and Soto (2005: 10).

In Argentina, the 'failure' of ISI owed at least as much to the economic shocks of the early 1970s as to the 'problem' of the state, and the 'ISI of the 1950s and 1960s was not that bad at fostering growth' (Taylor, 1999: 5). In this context, and in view of the spectacular economic meltdown that resulted from excessive deregulation in 2001, demands for the state to become more directive were, if not inevitable, then certainly predictable (Riggirozzi, 2009). As a result, the governments of Nestor Kirchner and Cristina Fernandez de Kirchner have sought to re-create the alliance between industrialists, labour and the public sector that was typical of Peronist economic expansion in the 1940s-1960s. But as Grugel (2009) and Wylde (2011) note, there are also points of departure in this new version of Peronism. The links with the labour movement are more fragmented, perhaps explaining the Kirchner governments' decision to embrace welfare policies that encompass the non-unionized working class. At the same time, there has been a conscious effort to conciliate business (Etchemendy and Collier, 2007; Wylde, 2011). The result is selective protectionism for manufacturing, a concern to try and limit inflation through managing prices in the internal market for key household goods and interventions to encourage labour to negotiate rather than strike for higher wages (Riggirozzi, 2009). These policies have allowed manufacturing for the domestic market and for export to play a vital role in Argentina's economic recovery since 2003. Indeed, industrial recovery has meant that the export of manufactures has outstripped those of unprocessed agricultural goods (Bezchinsky et al., 2007, in Wylde, 2011). ${ }^{3}$ This has been accompanied by limited nationalizations, most emblematically of the national airline, Aerolineas Argentinas, and water provision in Buenos Aires; the creation of new institutions such as Energía Argentina Sociedad Anónima (ENARSA) in 2004 which regulates the gas and energy sector; and contributions to the development of regional infrastructure (Carciofi, 2012).

3. The financial sector has lost the prominence it achieved in the 1990s. In contrast to both the earlier period of ISI and the neoliberal years, there is a new reluctance in Latin America with regard to external borrowing (Cooper and Momani, 2005). 
Table 4. Latin America and the Caribbean: Evolution of Goods Exports by

Technology Intensity and Factor Intensity, 1990-1999 and 2000-2009 (percentage average annual growth rates)

\begin{tabular}{lccccc}
\hline & \multicolumn{2}{c}{$\begin{array}{c}\text { Latin America } \\
\text { and the Caribbean }\end{array}$} & & \multicolumn{2}{c}{ South America } \\
\cline { 2 - 3 } \cline { 5 - 6 } & $\mathbf{1 9 9 0 - 1 9 9 9}$ & $\mathbf{2 0 0 0 - 2 0 0 9}$ & & $\mathbf{1 9 9 0 - 1 9 9 9}$ & $\mathbf{2 0 0 0 - 2 0 0 9}$ \\
\hline Primary products & 2.6 & 11.4 & & 2.7 & 13.0 \\
Natural resource-based manufactures & 7.5 & 8.9 & & 6.8 & 9.4 \\
Extractive industries & 2.6 & 8.2 & & 2.4 & 8.8 \\
Agriculture, hunting, forestry and fisheries & 6.0 & 9.2 & & 4.8 & 11.1 \\
Mining and quarrying & 0.5 & 7.7 & & 1.0 & 7.6 \\
Manufacturing industries & 14.2 & 6.0 & & 5.9 & 10.1 \\
\hline
\end{tabular}

Source: ECLAC (2010d: 79).

In Bolivia and Ecuador, in contrast, growth rests rather more exclusively on primary commodity exports and the natural resource boom. ${ }^{4}$ Oil provides around 35 per cent of Ecuador's GDP (World Bank, 2011). Both Ecuador and Bolivia have benefited from rising demand for oil and minerals in China, and to a lesser extent India, with annual growth of around 5 per cent per annum since 2006 (ECLAC, 2010c). Chinese exports to Latin America jumped by an annual rate of 42 per cent to US\$21.668 billion (ECLAC, 2004: 184). China has even joined the Inter-American Development Bank (IADB), contributing US\$ 350 million and paving the way for Chinese capital to invest in the infrastructural expansion that is taking place across the region. China has also negotiated a US\$ 12 billion development fund in Venezuela, and lent Ecuador US\$ 1 billion to build a hydroelectric plant (Romero and Barrionuevo, 2009).

The current natural resources boom is without precedent in recent history. It is different from the pre-ISI export period when the value of Latin America's exports declined steadily and the region's chief market centred on the US (Jenkins and Dussel Peters, 2010). As such, it is difficult to predict with certainty the extent to which export growth now offers firmer foundations for longer-term stability and economic diversification. The World Bank (2009) is pessimistic about the chances of diversifying Bolivia's export profile away from energy without more focused reforms to support it, while Gudynas (2010) argues that the 'new extractivism', meaning the intensive and extensive exploitation and export of natural resources, deepens reliance on global markets and risks concentration on a small portfolio of products. The extent of this trend is revealed in Table 4 .

4. The boom has transformed growth across the region as a whole. Although the global financial crisis disrupted regional growth slightly in 2008 and 2009, when exports fell abruptly by 24 per cent overall and mining exports by a spectacular 42.3 per cent, by 2010 Latin America was growing again by an impressive 6 per cent overall, with mining exports up by 29 per cent (ECLAC, 2010b). 
There is, then, an enormous challenge facing both Bolivia and Ecuador, namely, how to manage growth that derives almost entirely from the natural resource sector. Both Morales and Correa have resisted the temptation to nationalize the energy sector or introduce state monopolies. Indeed, despite proclamations of a 'nationalization' of gas, President Morales has actually pursued a new pact with private corporations that would establish majority (but not outright) ownership for the state whilst seeking to redefine corporate responsibilities and increase state revenues (Rochlin, 2007). In Ecuador, even before President Correa was elected in 2006, one of the largest of the oil fields, owned by the US Occidental Petroleum, was brought into national ownership, prompting speculation that more nationalizations were to come. In fact, the view that exploitation in conjunction with the private sector would provide the only realistic route to increasing revenues prevailed (Bebbington and Humphreys Bebbington, 2011). Despite initially radical and environmental rhetoric, once in office President Correa focused on maximizing income to the Treasury without disrupting oil production (Tockman, 2010). Legislation has been introduced to increase the government's share of windfall profits, along with higher taxes on oil production. The threat of expropriation has been used strategically, in order to force multinational companies to renegotiate contracts. At the same time, new concessions were granted to a range of oil companies including Spain's REPSOL, Chile's ENAP and China's PetroOriental, which agreed to pay a flat fee for oil production, increasing Ecuador's share in oil profits and releasing it from the insecurity of global oil prices (Financial Times, 24 November 2010). It is only those companies that have refused to renegotiate that are scheduled for expropriation, with compensation.

Natural resource policy, then, is to increase the volume of revenue to government rather than bring the export sector into public ownership, meaning that both Bolivia and Ecuador have opted to encourage production. There are, inevitably, long-term development risks inherent in this strategy. In the first place, there is the possibility that intensive exploitation will aggravate environmental degradation which is already a source of concern (Saguier, 2012). There is also a danger that, by generating 'easy' revenues, governments will be shielded from the need to tackle some of the deeper issues around diversification of the economy and productivity and will be able to avoid tackling the tax issue. Export dependence potentially squeezes the region's industrial competitiveness and locks it into deepening dependence on primary production - exactly what most development strategies in the twentieth century sought to escape from (ECLAC, 2008; Jenkins and Dussel Peters, 2010). Governments in Bolivia and Ecuador have taken a more activist approach to development and managing growth; but their policies are not directing the economy towards diversification over the long term. Moreover, there is even a question mark as to how far governments can effectively protect workers in the energy sector or even demand the introduction of health and safety reforms which might hamper productivity. 
These questions go to the heart of the emerging paradox within postneoliberal economic governance: the state is developing greater fiscal capacity (and using it to make some important investments in welfare) through export expansion at the expense of broadening the economic base. Even in Argentina, where the export portfolio is considerably more diverse than in Bolivia and Ecuador, the weight of primary commodities, both raw and processed, has grown steadily since around 2003. The 'paradox of plenty' has disrupted development disastrously in Latin America in the past (Karl, 1997). It is hard to see how even careful management of the income from the boom will, on its own, prevent the vulnerabilities that are inherent in dependence on primary production doing so again.

\section{CONCLUSION}

To sum up, we have argued that contemporary post-neoliberal projects in Ecuador, Bolivia and Argentina present clear differences but should be understood in the context of national aspirations for growth, welfare and citizenship; and that post-neoliberalism is not so much an attempt to return to state capitalism as to refashion the identity of the state, redefine the nature of collective responsibilities, build state capacity and rethink who national development is for. In this sense, the economic, social and political projects associated with post-neoliberalism - the citizenship agenda and the growth strategy - could be said to complement one another, for as Keck and Neara (2006) incisively argue, rebuilding the state is not an anodyne project of growth for growth's sake in Latin America but the expression of a profoundly political intention to 'make the state public' and ensure that it is better able to defend the public interest. Overall, in all three cases, there is evidence that the state is more visible and proactive in politics, social policy and the economy. Politically, there seems to be a genuine shift towards imagining new forms of democratic belonging (though these are not without their problems) and establishing new state-society relationships to support welfare spending. But in the economic domain growth is tending to mask some serious underlying concerns, especially around dependence on primary exports. There are, unquestionably, risks ahead as a consequence. States may be able to enhance their fiscal autonomy now by taking advantage of the export boom, only for the long-term problems of commodity dependence to strike again; equally the current governments may run into conflict with their own electorates over energy exploitation, the pace and the manner of redistribution or strategies to contain inflation and promote economic stability.

All of this means that it is easy to dismiss post-neoliberalism as a series of minor adjustments to what is essentially unreformed open market governance (Radice, forthcoming). Scholars who understand globalization to have effectively ended opportunities for meaningful state action are unable 
to conceive of post-neoliberalism as possible, at least not without a wholesale restructuring of the capitalist global order. Politically, meanwhile, whether post-neoliberalism is understood as a genuine attempt at building a more democratic politics also comes down, to some extent, to what constitutes democracy and the importance (or not) of horizontal forms of accountability, identity politics and voice within democratic systems (see Peruzzotti, 2006). We have tried to offer a nuanced argument here that avoids both excessive polemic and idealism about the new left and the post-neoliberal project, recognizes that policy autonomy is an important aspiration for states and people in the developing world even in conditions of uncertainty, weakness and global integration, and acknowledges that representative democracy requires participation of various sorts, social citizenship and state capacity to deliver, as well as institutional resilience. As such, we understand postneoliberalism, with all its fragilities, to reflect an attempt to deliver a democratic and inclusive social contract in Latin America within the confines of market-oriented, export-led growth.

\section{REFERENCES}

Albro, R. (2005) 'The Indigenous in the Plural in Bolivian Oppositional Politics', Bulletin of Latin American Research 24(4): 433-53.

Almeida, P. and H. Johnston (2006) 'Neoliberal Globalization and Popular Movements in Latin America', in H. Johnston and P. Almeida (eds) Latin American Social Movements Globalization, Democratization and Transnational Networks, pp. 3-18. London: Rowman \& Littlefield.

Babb, S. (2009) Behind the Development Banks: Washington Policy, World Politics and the Wealth of Nations. Chicago, IL: University of Chicago Press.

Bebbington, A. and D. Humphreys Bebbington (2011) 'An Andean Avatar: Post-Neoliberal and Neoliberal Strategies for Securing the Unobtainable', New Political Economy 16(1): 131-45.

Benton, A. (2008) 'Political Institutions, Hydrocarbons Resources, and Economic Policy Divergence in Latin America'. Paper presented at the American Political Science Association Annual Meeting, Boston, MA (28-31 August).

Bezchinsky, G., M. Dinerzon, L. Guissani and O. Caino (2007) 'Inversion Extranjera Directa en la Argentina. Crisis, Restructuracion y Nuevas Tendencias despues de la convertabilidad' ['Foreign Direct Investment in Argentina. Crisis, Restructuring and Trends after the Convertibility']. Project Paper. Santiago: CEPAL.

Birdsall, N. and J.L. Londono (1998) 'No Tradeoff: Efficient Growth via More Equal Human Capital in Latin America', in N. Birdsall, C. Graham and R. Sabot (eds) Beyond Tradeoffs: Market Reforms and Equitable Growth in Latin America, pp. 111-45. Washington, DC: Brookings Institution Press and Inter-American Development Bank.

Birdsall, N. and A. de la Torre (2001) Washington Contentious Economic Policies for Social Equity in Latin America. Washington, DC: Carnegie Endowment for International Peace.

Birdsall, N., A. de la Torre and R. Menezes (2009) Fair Growth: Economic Policies for Latin America's Poor and Middle Class Majority. Washington, DC: Center for Global Development/Inter-American Dialogue.

Burton, M., R. Gunther and J. Higley (1992) 'Introduction: Elite Transformation and Democratic Regimes', in J. Higley and R. Gunther (eds) Elites and Democratic Consolidation in Latin America and Southern Europe, pp. 1-37. Boulder, CO: Rowman \& Littlefield.

Carciofi, R. (2012) 'Infrastructure: Learning and Cooperation for the Provision of Regional Public Goods', in P. Riggirozzi and D. Tussie (eds) The Rise of Post-Hegemonic Regionalism: 
The Case of Latin America. Dordrecht: Springer UNU/CRIS Series on Comparative Regionalism (forthcoming).

Castañeda, J. (2006) 'Latin America's Left Turn', Foreign Affairs 85(3): 28-43.

Castañeda, J. and M. Morales (2008) Leftovers: Tales of the Latin American Left. London: Routledge.

Centeno, M. (2009) 'El Estado en America Latina' ['The State in Latin America'], Revista CIDOB d'Afers Internacionals 85: 11-31.

Chorev, N. and S. Babb (2009) 'The Crisis of Neoliberalism and the Future of International Institutions: A Comparison of the IMF and the WTO', Theory and Society 38(5): 459-84.

Clements, B., C. Faircloth and M. Verhoeven (2007) 'Public Expenditure in Latin America: Trends and Key Policy Issues', CEPAL Review 93: 37-60. http://www.eclac.org/ publicaciones/xml/1/32791/RVI93ClementsOtros.pdf/ (accessed 20 September 2011).

Cogliandro, G. (2010) 'El programa Asignación Universal por Hijo para Protección Social y los cambios en los Programas de Transferencias Condicionadas' ['Universal Child Allowance Programme for Social Protection and the Changes in Conditiononal Transfer']. Published in Fundacion Siena. http://mpra.ub.uni-muenchen.de/23846/ (accessed 1 February 2011).

Conaghan, C.M. (2008) 'Ecuador: Correa's Plebiscitary Presidency', Journal of Democracy 19(2): 46-60.

Cook, M.L. (1998) The Politics of Labor Law Reform: Comparative Perspectives on the Mexican Case. Ithaca, NY: Cornell University, School of Industrial and Labor Relations.

Cooper, A. and B. Momani (2005) 'Negotiating out of Argentina's Financial Crisis: Segmenting the International Creditors', New Political Economy 10(3): 305-20.

Cortes, R. (2009) 'Social Policy in Latin America in the Post-Neoliberal Era', in J. Grugel and P. Riggirozzi (eds) Governance After Neoliberalism in Latin America, pp. 49-66. Basingstoke: Palgrave Macmillan.

Dinerstein, A.C. (2007) 'Workers' Factory Takeovers and New State Policies: Towards the Institutionalization of Non-Governmental Public Action in Argentina', Policy and Politics 35(3): 529-50.

Eckstein, S. (2006) 'Urban Resistance to Neoliberal Democracy in Latin America', Colombia Internacional 63: 12-39.

Eckstein, S. and T. Wickham-Crowley (2003) 'Struggles for Social Rights in Latin America: Claims in the Arenas of Subsistence, Labor, Gender and Ethnicity', in S. Eckstein and T. Wickham-Crowley (eds) Struggles for Social Rights in Latin America, pp. 1-56. London: Routledge.

ECLAC (2004) 'A Decade of Social Development in Latin America, 1990-1999'. Santiago de Chile: ECLAC.

ECLAC (2007) 'Economic Growth with Equity. Challenges for Latin America'. Santiago de Chile: United Nations Publications.

ECLAC (2008) 'Economic Survey of Latin America and the Caribbean 2007-2008'. http://www. eclac.org/cgi-bin/getProd.asp?xml=/publicaciones/xml/3/33873/P33873.xml\&xsl=/de/tpl-i/ p9f.xsl\&base=/tpl-i/top-bottom.xsl (accessed 2 February 2011).

ECLAC (2009) Statistical Yearbook for Latin America and the Caribbean, 2009. Santiago de Chile: CEPAL.

ECLAC (2010a) Social Panorama of Latin America. Santiago de Chile: CEPAL.

ECLAC (2010b) 'Achieving the Millennium Development Goals with Equality in Latin America and the Caribbean'. Santiago de Chile: CEPAL

ECLAC (2010c) 'China to Become the Region's Second Export Market Midway through the Next Decade'. Santiago de Chile: CEPAL

ECLAC (2010d) 'Latin America and the Caribbean in the World Economy: 2009-2010'. Santiago de Chile: CEPAL

Etchemendy S. and R.B. Collier (2007) 'Down But Not Out: Union Resurgence and Segmented Corporatism in Argentina (2003-2007)', Politics and Society 35(3): 363-401.

Feijoo, M. (2001) Nuevo País, Nueva Pobreza [New Country, New Poverty]. Buenos Aires: Fondo de Cultura Económica. 
Financial Times (2010) 'Ecuador Reaches Deal with Most Oil Companies', 24 November.

Foxley, A. (2010) Markets vs States: Post Crisis Economics in Latin America. Washington, DC: Carnegie Endowment. http://carnegieendowment.org/files/market_versus_state.pdf (accessed 2 February 2011).

Gamble, A. (2010) 'New World Order? The Aftermath of Financial Crisis', Political Insight 1(1): 17-19.

Goldfrank, B. (2011) Deepening Local Democracy in Latin America: Participation, Decentralization and the Left. University Park, PA: Pennsylvania State University Press.

Goldfrank, B. and A. Schrank (2009) 'Municipal Neoliberalism and Municipal Socialism: Urban Political Economy in Latin America', International Journal of Urban and Regional Research 32(2): 443-62.

Gray Molina, G. (2008) 'Bolivia's Long and Winding Road'. Inter-American Dialogue Working Paper. http://www.thedialogue.org/PublicationFiles/Bolivia\&apos;s\%20Long\% 20and\%20Winding\%20Road\%20-\%20George\%20Gray\%20Molina\%20(July\%202008).pdf (accessed 2 February 2011).

Green, D., R. King and M. Miller-Dawkins (2010) 'The Global Economic Crisis and Developing Countries: Impact and Responses'. Working Draft. Oxford: Oxfam.

Grugel, J. (2009) 'Basta de Realidades, Queremos Promesas: Democracy After the Washington Consensus', in J. Grugel and P. Riggirozzi (eds) Governance After Neoliberalism in Latin America, pp. 25-48. Basingstoke: Palgrave Macmillan.

Grugel, J. and P. Riggirozzi (2007) 'The Return of the State in Argentina', International Affairs 83(1): 87-107.

Grugel, J. and P. Riggirozzi (eds) (2009) Governance After Neoliberalism in Latin America. Basingstoke: Palgrave Macmillan.

Gudynas, E. (2010) 'The New Extractivism of the 21st Century: Ten Urgent Theses about Extractivism in Relation to Current South American Progressivism'. Americas Program Report. Washington, DC: Center for International Policy.

Gwynne, R. and C. Kay (2000) 'Views from the Periphery: Futures of Neoliberalism in Latin America', Third World Quarterly 21(1): 141-56.

Haggard, S. (1990) Pathways from the Periphery: The Politics of Growth in Newly Industrializing Countries. Ithaca, NY: Cornell University.

Haggard, S. and R. Kaufman (eds) (1992) The Politics of Economic Adjustment: International Constraints, Distributive Conflicts, and the State. Princeton, NJ: Princeton University Press.

Hagopian, F. (1992) 'The Compromised Consolidation: The Political Class in the Brazilian Transition', in S. Mainwaring, G. O'Donnell and J.S. Valenzuela (eds) Issues in Democratic Consolidation: The New South American Democracies in Comparative Perspective, pp. 24393. Notre Dame, IN: University of Notre Dame Press.

Harvey, D. (2005) A Brief History of Neoliberalism. New York: Oxford University Press.

Hay, C. (2010) 'Pathology without Crisis: The Strange Demise of the Anglo-Liberal Growth Model'. Leonard Schapiro Lecture at the Annual Political Studies Conference, Edinburgh. http:/www.yada-yada.co.uk/Blackwell/GovernmentAndOpposition/ GovernmentAndOpposition.html (accessed 12 September 2011).

Hershberg, E. and F. Rosen (2006) 'Turning the Tide?', in E. Hershberg and F. Rosen (eds) Latin America After Neoliberalism, pp. 1-25. London: The New Press. http://www.nytimes.com/ 2009/04/16/world/16chinaloan.html?_r=1\&ref=global-home (accessed 16 April 2009).

IADB (2006) The Politics of Policies: Economic and Social Progress in Latin America, 2006 Report. Washington, DC: IADB.

Isuani, A. (2010) 'The Argentine Welfare State: Enduring and Resisting Change', International Journal of Social Welfare 19(1): 104-14.

Jenkins, R. and E. Dussel Peters (eds) (2010) China and Latin America: Economic Relations in the Twenty First Century. Bonn: German Development Institute.

Karl, T. (1997) The Paradox of Plenty: Oil Booms and Petro-states. Berkeley, CA: University of California Press. 
Kaup, B. (2010) 'Bolivia's Nationalised Natural Gas: Social and Economic Stability Under Morales'. London: London School of Economics. http://www2.1se.ac.uk/IDEAS/ publications/reports/pdf/SU005/kaup.pdf (accessed 20 September 2011).

Keck, M. and R. Neara (2006) 'Civil Society and State Building in Latin America', LASA Forum XXVII(1): 30-32.

Kozloff, N. (2008) Revolution! South America and the Rise of the New Left. Basingstoke: Palgrave Macmillan.

La Nación (2008) 'Las Claves de los Cambios Salariales del Servicio Doméstico' ['Key Changes in Domestic Service Salaries']. 18 December. http://www.lanacion.com.ar/1082065-lasclaves-de-los-cambios-salariales-del-servicio-domestico (accessed 15 September 2011).

Lazar, S. (2008) El Alto, Rebel City: Self and Citizenship in Andean Bolivia. Durham, NC: Duke University Press.

Leiva, F.I. (2008) Latin American Neostructuralism: Contradictions of Post-Neoliberal Development. Minnesota, MN: Minnesota University Press.

Lievesley, G. and S. Ludlam (2009) Reclaiming Latin America: Experiments in Radical Social Democracy. London: Zed Books.

Lledo, V., A. Schnieder and M. Moore (2004) 'Governance, Taxes and Tax Reform in Latin America'. IDS Working Paper 221. Brighton: IDS

Lo Vuolo, R., D. Raventós and P. Yanes (2010) 'El Ingreso Ciudadano-Renta Básica ante la Crisis Económica y los Ataques a los Derechos Sociales y Laborales' ['Basic Income in Times of Crisis and of Attacks on Social and Labour Rights']. http://www.sinpermiso.info/ textos/index.php?id=3550 (accessed 10 January 2011).

Lopez-Calva, L.F. and N. Lustig (2010) Declining Inequality in Latin America: A Decade of Progress? Washington, DC: Brookings Institution Press and UNDP.

Lustig, N. and D. McLeod (2009) 'Are Latin America's New Left Regimes Reducing Inequality Faster? Addendum to Poverty, Inequality and the New Left in Latin America'. Available at: http://www.wilsoncenter.org/publication/are-latin-americas-new-left-regimesreducing-inequality-faster-addendum-to-poverty (accessed 19 December 2010).

Morales, E. (2005) 'I Believe Only in the Power of the People'. Speech delivered by President Evo Morales. http://www.countercurrents.org/bolivia-morales221205.htm (accessed 2 February 2011).

Mosley, P., B. Chiripanhura, J. Grugel, N. Fiess and B. Thirkell-White (forthcoming) The Politics of Poverty Reduction. Oxford: Oxford University Press.

Murh, T. (2010) 'Counter-hegemonic Regionalism and Higher Education for All: Venezuela and the ALBA', Globalisation, Societies and Education 8(1): 39-57.

Nelson, J. (1989) Fragile Coalitions: The Politics of Economic Adjustment. Washington, DC: Overseas Development Council.

O'Donnell, G. and P. Schmitter (1986) 'Transition from Authoritarian Rule: Tentative Conclusions about Uncertain Democracies', in G. O'Donnell, P.C. Schmitter and L. Whitehead (eds) Transitions From Authoritarian Rule: Comparative Perspectives, pp. 15-36. Baltimore, MD and London: The Johns Hopkins University Press.

OECD (2010) 'Latin America's Middle Sectors: Key Players in a Renewed Social Contract?'. Policy Insights 93. Paris: OECD.

Oxhorn, P. (2009) 'Citizenship as Consumption or Citizenship as Agency: Comparing Democratizing Reforms in Bolivia and Brazil'. Paper prepared for presentation at the annual meeting of the American Political Science Association, Toronto (3-6 September).

Pagina 12 (2010) 'La Asignación llego a los Hijos de los Temporarios' ['Universal Allowance Reaches Temporary Workers' Children']. 2 December. http://www.pagina12.com.ar/ diario/elpais/1-157916-2010-12-02.html (accessed 21 September 2011).

Pagina 12 (2011) 'La UNASUR, Preocupada por la Crisis Mundial' ['UNASUR Worried by the Global Crisis']. 29 July. http://www.pagina12.com.ar/diario/elpais/1-173306-2011-0729.html (accessed 15 September 2011).

Panizza, F. (2005) 'Unarmed Utopia Revisited: The Resurgence of Left-of-Centre Politics in Latin America', Political Studies 53(4): 716-34. 
Panizza, F. (2009) Contemporary Latin America: Development and Democracy Beyond the Washington Consensus. London: Zed Books.

Peck, J., T. Nik and N. Brenner (2010) 'Postneoliberalism and its Malcontents', Antipode 41(1): 94-116.

Peruzzotti, E. (2006) 'Demanding Accountable Government: Citizens, Politicians and the Politics of Representation', in S. Levitsky and M. V. Murillo (eds) Argentine Democracy: The Politics of Institutional Weakness, pp. 229-49. University Park, PA: Penn State University.

Portes, A. and K. Hoffman (2003) 'Latin American Class Structures: Their Composition and Change during the Neoliberal Era', Latin American Research Review 38(1): 38-52.

Przeworski, A. (2011) 'La Democracia y sus Controles' ['Democracy and (Electoral) Control']. Interview with Natalia Aruguete, Pagina 12, 28 March. http://www.pagina12. com.ar/diario/dialogos/subnotas/21-52759-2011-03-28.html\#arriba (accessed 20 September 2011).

Radice, H. (forthcoming) 'Markets and States within Global Global Capitalism: What's "Post" About Postneoliberalism?'. Paper to be presented at the BISA/ISA Conference, Edinburgh (20-22 June 2012).

Riggirozzi, P. (2009) 'After Neoliberalism in Argentina: Reasserting Nationalism in an Open Economy', in J. Grugel and P. Riggirozzi (eds) Governance After Neoliberalism in Latin America, pp. 98-112. Basingstoke: Palgrave Macmillan.

Roberts, K. (1998) Deepening Democracy? The Modern Left and Social Movements in Chile and Peru. Stanford, CA: Stanford University Press.

Roberts, K. (2008) ‘¿Es Posible una Socialdemocracia en América Latina?’ ['Is Social Democracy Possible in Latin America?'], Nueva Sociedad 217: 86-98.

Rochlin, J. (2007) 'Latin America's Turn to the Left and the New Strategic Landscape: The Case of Bolivia', Third World Quarterly 8(7): 1327-42.

Romero, S. and A. Barrionuevo (2009) 'Deals Help China Expand Sway in Latin America'. New York Times 16 April. http://www.nytimes.com/2009/04/16/world/16chinaloan.html (accessed 23 May 2010).

Ruckert, A. and L. MacDonald (2010) 'The Post Neoliberal Mix: New State Practices in Latin America's Big Three'. Unpublished paper. http://www.yorku.ca/robarts/projects/canadawatch/turning_point/pdfs/Macdonald_Ruckert (accessed 2 February 2011).

Sachs, J. (2010) 'Robin Hood Tax's Time Has Come', The Guardian 18 March.

Sader, E. (2008) 'The Weakest Link? Neoliberalism in Latin America', New Left Review 52: 5-31.

Saguier, M. (2012) 'Socio-Environmental Regionalism in South America: Tensions in New Development Models', in P. Riggirozzi and D. Tussie (eds) The Rise of PostHegemonic Regionalism: The Case of Latin America. Dordrecht: Springer UNU/CRIS (forthcoming).

Silva, P. (2008) In the Name of Reason: Technocrats and Politics in Chile. University Park, PA: Penn State University Press.

Solimano, A. and R. Soto (2005) Economic Growth in Latin America in the Late Twentieth Century: Evidence and Interpretation. Santiago: ECLAC.

Stallings, B. (1992) 'International Influence on Economic Policy: Debt, Stabilization, and Structural Reform', in S. Haggard and R. Kaufman (eds) The Politics of Economic Adjustment: International Constraints, Distributive Conflicts, and the State, pp. 41-88. Princeton, NJ: Princeton University Press.

Stokes, S. (2009) 'Globalisation and the Left in Latin America'. Online paper. http://www.yale. edu/macmillanreport/resources/Stokes_GlobalizationLeft.pdf (accessed 1 February 2011).

Taylor, L. (1999) After Neoliberalism: What Next for Latin America. Ann Arbor, MI: University of Michigan Press.

Tockman, J. (2010) 'Varieties of Post-neoliberalism: Ecuador and Bolivia's Divergent Paths of Citizenship, Participation and Natural Resource Policy'. Paper presented at the 2010 Congress of the Latin American Studies Association, Toronto, Canada (6-9 
October). http://lasa.international.pitt.edu/members/congress-papers/lasa2010/files/3867. pdf (accessed 1 February 2011).

UNDP (2010) Acting on the Future: Breaking the Intergenerational Transmission of Inequality. Regional Human Development Report for Latin America and the Caribbean. New York: UNDP.

Van Cott, D.L (2005) From Movements to Parties in Latin America: The Evolution of Ethnic Politics. Cambridge: Cambridge University Press.

te Velde, D. (2008) 'The Global Financial Crisis and Developing Countries: Which Countries are at Risk and What can be Done?'. ODI Background Note. London: Overseas Development Institute.

Vilas, C. (2006) 'The Left in South America and the Resurgence of National-Popular Regimes', in E. Hershberg and F. Rosen (eds) Latin America After Neoliberalism, pp. 232-51. London: NACLA/The New Press.

World Bank (2003) Argentina. Crisis and Poverty 2003: A Poverty Assessment. Volume I: Main Report, PREM. Report No. 26127. Washington, DC: The World Bank.

World Bank (2004) Inequality in Latin America: Breaking with History? Washington, DC: The World Bank. http://www-wds.worldbank.org/servlet/WDSContentServer/ WDSP/IB/2004/06/22/000160016_20040622141728/Rendered/PDF/28989.pdf (accessed 20 September 2011).

World Bank (2009) Strengthening Bolivian Competitiveness: Export Diversification and Inclusive Growth. Washington, DC: The World Bank. http://siteresources.worldbank.org/ EXTLACREGTOPECOPOL/Resources/StrengtheningBoliviacompetitiveness.pdf

World Bank (2011) 'Ecuador: Country Brief'. Washington, DC: The World Bank. http:// web.worldbank.org/WBSITE/EXTERNAL/COUNTRIES/LACEXT/ECUADOREXTN/ 0, contentMDK:20198430 pagePK:141137 piPK:141127 theSitePK:325116,00.html

Wylde, C. (2011) 'State, Society and Markets in Argentina: The Political Economy of Neodesarrollismo under Nestor Kirchner, 2003-2007', Bulletin of Latin American Research 30(4): 436-45.

Jean Grugel is Professor of International Development at the University of Sheffield. Her research interests span questions of development, citizenship, human rights and democracy. Recent publications include Governance after Neoliberalism in Latin America (with Pía Riggirozzi, Palgrave Macmillan, 2009), Critical Perspectives on Global Governance: Rights and Regulation in Governing Regimes (with Nicola Piper, Routledge, 2007) and Democratization (Palgrave, 2012) as well as articles in International Sociology, Journal of Latin American Studies and Human Rights Quarterly.

Pía Riggirozzi is Lecturer in Global Politics at the University of Southampton. Her research focuses on political economy of development and regionalism. Her publications include Advancing Governance in the South: What Roles for IFIs in Developing States? (Palgrave, 2009), 'Region, Regionness and Regionalism in Latin America: Towards a New Synthesis' (New Political Economy, 2011), and The Rise of Post-Hegemonic Regionalism: The Case of Latin America (edited with D. Tussie, Springer-UNU/CRIS, 2012). 